\author{
Anna PRUSAK ${ }^{1}$ \\ Gene ROWE ${ }^{2}$ \\ Jacek STROJNY ${ }^{3}$
}

\title{
IS GMO "SUSTAINABLE"? A REVIEW OF THE ENVIRONMENTAL RISKS OF GM PLANTS IN COMPARISON WITH CONVENTIONAL AND ORGANIC CROPS
}

\begin{abstract}
The present paper aims to review and discuss potential and existing risks of GM crops to the environment, in comparison with organic and conventional agriculture. The review of over 30 relevant papers on the environmental effects of modern agriculture allowed us to define five main sources of risks, namely: 1) Pollution by synthetic fertilizers and pesticides, 2) Exploitation of marginal lands and protection of natural habitats, 3) Gene flow, invasiveness and "superweeds", 4) Impact on non-target species, particularly pollinators, 5) Biodiversity of crops and wildlife. Although these effects are typically considered with respect to GM crops, the paper compares them with conventional and organic systems. The review shows that each factor, except for the "Gene flow, invasiveness and superweeds" (which is a risk specific to GM crops), may have positive and negative effect dependent on the breeding method. For example, conventional crops require the use of a large amount of synthetic fertilizers and pesticides, unlike organic crops, while GM agriculture reduces the use of pesticides. Moreover, some risks typically associated with transgenic crops, i.e. decrease of genetic biodiversity, may also arise from conventional agriculture. The paper concludes that there is no perfect agricultural option and trade-offs are needed to satisfy the need for sustainability.
\end{abstract}

Keywords: GMO, sustainability, environmental risks, food production

\section{INTRODUCTION}

It is not possible to discuss environmental effects of agriculture without referring to "sustainability". The term "sustainable agriculture", "sustainable farming" or "sustainable agricultural development" is an important contemporary issue in animal and plant production addressed by many institutions and politicians ${ }^{4}$. The concept of agricultural sustainability was originally defined by the Food, Agriculture, Conservation, and Trade Act of 1990 (FACTA) as an "...integrated system of plant and animal production having a site-specific application...". Under the law, this system should fulfill several long term objectives, notably: “...satisfy human food and fiber needs; enhance environmental quality and the natural resource base upon which the agricultural economy depends; make the most efficient use of nonrenewable re-

${ }^{1} \mathrm{PhD}$ Anna Prusak, Department of Quality Management, Krakow University of Economics, Krakow, Rakowicka St. 27, 31-510 Krakow, Poland; e-mail: anna.prusak@uek.krakow.pl, phone: +48 122937516.

${ }^{2} \mathrm{PhD}$ Gene Rowe, Gene Rowe Evaluations, 12 Wellington Road, Norwich, UK; e-mail: generowe00@gmail.com, phone: +44 1603492117.

3 PhD Jacek Strojny, Department of Economics, Rzeszow University of Technology, Rzeszow, Powstancow Warszawy Av., 35-959 Rzeszow, jstrojny@ prz.edu.pl, phone: +48 178651403 (corresponding author).

${ }^{4} \mathrm{~W}$. Wagner, Sustainable agriculture: how to sustain a production system in a changing environment, "International Journal for Parasitology" 29/1 (1999), p. 1-5. 
sources and on-farm resources and integrate, where appropriate, natural biological cycles and controls; sustain the economic viability of farm operations; and enhance the quality of life for farmers and society as a whole...". . A sustainable agricultural system should be therefore "....resource-conserving, socially supportive, commercially competitive and environmentally sound...", producing abundant and wholesome food without polluting the environment or depleting natural resources, and also being in line with socio-economic values ${ }^{7}$.

There are four types of farming systems usually reported with respect to sustainability, that is: (i) conventional, (ii) organic, (iii) integrated, and (iv) transgenic. In addition, a direct drilling system is also referenced in some studies ${ }^{8}$. The term "conventional" refers to an industrialized agricultural production, highly mechanized, promoting monocultures and using synthetic inputs such as chemical fertilizers and pesticides, aiming at maximum productivity and profitability ${ }^{9}$. In other words, the conventional model considers farms as factories and plants or animals as production units ${ }^{10}$. "Organic" (also called "ecological" in some countries) agriculture is described as a method encouraging the use of renewable resources and biodiversity, without artificial fertilizers, herbicides and pesticides, and without the use of genetically modified organisms (GMOs) $)^{11}$. "Integrated" systems postulate minimization of the use of synthetic fertilizers and pesticides, while supporting crop rotation as a natural method to improve crop productivity ${ }^{12}$. The fourth model is "transgenic" or "biotechnology" agriculture, based on the use of genetically modified organisms (GMOs).

The economic aspects of sustainability of conventional versus organic and integrated crops have been explored quite frequently ${ }^{13}$. These studies were based on the analysis of economic and environmental trade-offs between different agricultural systems, taking into account local conditions. A debate concerning the level to which an agricultural method is at the same time economically viable, able to provide plentiful, safe and nutritious food and offers maximum protection for natural ecosystems, becomes even more complex if transgenic agriculture is taken into consideration. The use of GM organisms in agriculture, especially for food and feed use, has become the subject of an intense debate, particularly in Europe ${ }^{14}$. Transgenic agricul-

\footnotetext{
5 www.nal.usda.gov.

${ }^{6}$ John Ikerd, quoted by Duesterhaus, 1990, p. 4. in: Sustainability's Promise, Journal of Soil and Water Conservation (Jan.-Feb. 1990) 45 (1): p.4

${ }^{7}$ Earles, 2005 Sustainable agriculture: An Introduction. [Internet]. ATTRA. <http://attra.ncat.org/attrapub/summaries/sustagintro.html>. [Accessed $11^{\text {th }}$ April 2008]

${ }^{8}$ Champeil, A, Fourbet, J, Doré, T and Rossignol, L (2004) Influence of cropping system on Fusarium head blight and mycotoxin levels in winter wheat. Crop Protection, 23 (6): 531-537

${ }^{9}$ Eicher, 2003 Organic Agriculture. A Glossary of Terms for Farmers and Gardeners. [Internet]. University of California Cooperative Extension 〈http://www.cehumboldt.ucdavis.edu/files/8286.pdf〉. [Accessed 11 ${ }^{\text {th }}$ April 2008]

${ }^{10}$ Ikerd, 1993 The need for a system approach to sustainable agriculture. Agriculture, Ecosystems \& Environment, 46 (1-4): 147-160

${ }^{11}$ Eicher, 2003 op. cit.

${ }^{12}$ Pacini, C, Wossink, A, Giesen, G, Vazzana, C and Huirne, R (2003) Evaluation of sustainability of organic, integrated and conventional farming systems: a farm and field-scale analysis. Agriculture, Ecosystems \& Environment, 95 (1): 273-288

${ }^{13}$ Andow \& Hidaka, 1998 Yield loss in conventional and natural rice farming systems. Agriculture, Ecosystems \& Environment, 70 (2-3): 151-158; Clark et al, 1999, Nitrogen, weeds and water as yield-limiting factors in conventional, low-input, and organic tomato systems. Agriculture, Ecosystems \& Environment, 73 (3):151-158

${ }^{14} \mathrm{M}$. Finucane, J. Holup, Psychosocial and cultural factors affecting the perceived risk of genetically modified food: an overview of the literature, "Social Sci. Medicine" 2005/60, p. 1603-1612; S. Noussair, Do consumers really refuse to buy genetically modified food?, "Econom. J." 114/1 (2004), p. 102-120; L. Pelizzoni, Democ-
} 
tural technology was initially promoted as an option that allows avoiding environmental pressures created by conventional agriculture, while maintaining its high productivity ${ }^{15}$. Yet, the unknown plausible effects of GM crops on health and the environment quickly generated a global conflict-ridden debate across countries ${ }^{16}$. The controversy surrounding GM crops has been reported in the mass media, scientific papers and quasi-scientific publications available online (e.g. 50 Harmful Effects of Genetically Modified Foods, 2000; Communication Guide to Improving Understanding of Food Biotechnology, 2001; InterAcademy Panel Initiative on Genetically Modified Organisms, 2006).

The aim of the present paper is to review and discuss potential and existing risks of GM crops to the environment, in comparison with other agricultural methods such as organic and conventional. The review is based on the assumption that "no method is perfectly sustainable" and trade-offs are needed to decide which agricultural system is optimal for a given region. Thus, to obtain a full picture, we would need to consider the health and economic impact of these crops, which have been the subject of other studies ${ }^{17}$.

\section{MATERIALS AND SCOPE OF THE STUDY}

The main objective of this paper is to review existing knowledge on the environmental impact of genetically modified crops. Factors influencing the environment have been identified based on definitions of "sustainability" and Environmental Impact Assessment (EIA). EIA is based on the Cartagena Protocol on Biosafety and provides a safety assessment framework for particular realizations of biotechnology ${ }^{18}$. Factors influencing the environment have been the subject of many studies. Relevant publications have been retrieved from national and international databases. These were mainly in English, but we also included several Polish articles.

In this paper, we review potential and existing risks of biotechnology crops to the environment, in comparison with other plant breeding methods such as organic and conventional agriculture. The term "risk" is mainly associated with negative events, being defined as, for example, "the possibility that an undesirable state of reality may occur", , or "the probability and consequences of adverse events" 20 . Subsequently, risk management is "...the process of weighting policy alternatives to accept, minimize or reduce assessed risks and to select and implement appropriate options..." 21 . Nevertheless, in this paper we decided to consider "risk" and "risk management" from a broader perspective, taking into account also benefits and opportunities. Factors that are the sources of different environmental risks include five categories: 1) Pollution by synthetic fertilizers and pesticides, 2) Exploitation of marginal lands and pro-

racy and the governance of uncertainty. The case of agricultural gene technologies, "J. Hazard. Materials" 2001/86, p. 205-222.

${ }^{15}$ Levidow \& Boschert, 2008 Coexistence or contradiction? GM crops versus alternative agricultures in Europe. Geoforum, 39 (1): 174-190

${ }^{16}$ L. Pelizzoni, op. cit.

${ }^{17}$ E.g. Prusak A., Schlegel-Zawadzka M., Food health quality of genetically modified crops - review of risks and benefits, "Military Pharmacy and Medicine" 2013/VI-2, p. 13-18.

${ }^{18}$ Linacre et al, 2006 Strategic environmental assessment for genetically modified organisms. Impact Assessment and Project Appraisal, 24 (1): 35-43

${ }^{19}$ Renn 1992 Risk communication: towards a rational discourse with the public. Journal of Hazardous Materials, 29: 465-519

${ }^{20}$ Slovic 2001 The risk game. Journal of Hazardous Materials, 86 (1-3): 17-24

${ }^{21}$ FAO/WHO, 1995 Application of risk analysis to food standards issues. Report on the joint FAO/WHO expert consultation, Geneva, Switzerland, 13-17 March 1995 
tection of natural habitats, 3) Gene flow, invasiveness and "superweeds", 4) Impact on nontarget species, particularly pollinators, 5) Biodiversity of crops and wildlife.

\section{REVIEW OF THE INFLUENCES OF GM, CONVENTIONAL AND ORGANIC AGRICULTURE ON ENVIRONMENTAL SUSTAINABILITY}

This section provides a description of the environmental factors with respect to conventional, organic and GM (transgenic) crops. These factors address GM traits such as herbicide tolerance and Bt-resistance and their positive and negative effects on the environment, in comparison with conventional and organic crops. Importantly, environmental effects should be discussed in the context of sustainability. The term "sustainable" refers to enhancing and preserving environmental quality and natural resources, which also satisfy human needs and improve the quality of life. Therefore, health and economic aspects of each agricultural production method should be also taken into consideration, and they have been addressed in other papers ${ }^{22}$.

\subsection{Pollution by synthetic fertilizers and pesticides}

Besides the health risk, excessive use of synthetic inputs in conventional breeding affects the environment. Studies conducted in many countries have detected pesticide residues in environmental samples including soil, water and plants ${ }^{23}$. Thus, transgenic agriculture is considered as the only economically viable alternative to conventional methods in reducing environmental (and dietary) exposure to pesticide residues. Two applications, most common in transgenic agriculture, determine the possibility of reduced use of synthetic chemicals in plant production: herbicide tolerance and insect resistance $(\mathrm{Bt})$. Herbicide resistant plants contain a gene which protects the crop against harmful effects of weed killers. They can be sprayed with low amount of the specific herbicide which kills only the weeds but not the crop. Insect resistant $(\mathrm{Bt})$ plants contain a gene isolated from the microorganism Bacillus thuringiensis, producing an insect-killing toxin. This modification allows the plants to produce their own toxin, so there is no more need to spray the crop $^{24}$. The advantages resulted from reduced spray of herbicides and insecticides carry enormous potential for keeping natural environment unpolluted. It was estimated that the cultivation of GM soybean, canola, cotton and maize reduced pesticide use by 22.3 million $\mathrm{kg}$ of formulated product $\mathrm{t}^{25}$.

\subsection{Exploitation of marginal lands and protection of natural habitats}

One of the major threats to natural environment is habitat loss due to the conversion of natural ecosystems to farmlands in response to growing food demand ${ }^{26}$. In addition to crops re-

\footnotetext{
${ }^{22}$ E.g. A. Prusak, M. Schlegel-Zawadzka, op. cit.

${ }^{23}$ E.g. Prudente et al, 2007 Persistent Toxic Substances in the Philippine Environment. Developments in Environmental Sciences, 7: 559-585; Gui et al, 2008 Development of a one-step strip for the detection of triazophos residues in environmental samples. Analytical Biochemistry, In Press, Uncorrected Proof, Available online 14 March 2008

${ }^{24} \mathrm{~J}$. van den Bergh, J. Holley, An environmental-economic assessment of genetic modification of agricultural crops, "Futures" 34/9-10 (2002), p. 807-822.

${ }^{25}$ Phipps \& Park, 2002 Environmental benefits of genetically modified crops: global and European perspectives on their ability to reduce pesticide use. Journal of Animal and Feed Sciences, 11: 1-18 in: Conner, Glare \& Nap, 2003 The release of genetically modified cops into the environment. Part II: Overview of ecological assessment. The Plant Journal, 33: 19-46

${ }^{26}$ Tilman et al, 2001 Diversity and Productivity in a Long-Term Grassland Experiment. Science, 294 (5543): 843-845
} 
sistant to insects and herbicides, transgenic technology may produce plants resistant to abiotic stresses, such as dry, salty or acidic soils. Not only is this a major benefit for developing countries since most of these are located in arid regions ${ }^{27}$, but this also represents a less soilinvasive alternative to conventional $\mathrm{crops}^{28}$, i.e. prevents soil erosion. The possibility of adaptation of marginal lands for farming purposes may therefore reduce the conversion of natural habitats, such as forests and grasslands, into croplands. However, due to the fact that such transgenic improvement involves polygenic traits, the progress in developing such plants is rather slow ${ }^{29}$.

\subsection{Gene flow, invasiveness and "superweeds"}

Gene flow between different species and spontaneous hybridization of cultivated crops with weedy relatives was documented a long time ago by Darwin $(1876)^{30}$. Extensive evidence of the capacity of cultivated crops to transfer their genetic material to wild varieties has been discussed by Ellstrand et al. ${ }^{31}$, who found that the spontaneous gene flow between crops and their wild relatives happens quite frequently. Subsequently, if transgenes express resistance to pests, diseases or environmental stresses, their introgression into weedy relatives of crops may improve particular fitness of the weed ${ }^{32}$. This may lead to creation of a "superweed" resistant to herbicides and difficult to fight off. In the case of Bt insect resistance crops, a transgenic toxin Bt persists in the soil for at least 18 months and can be transported to wild plants generating mutant weeds, which are resistant to pests ${ }^{33}$. The GM oilseed rape raises perhaps the most controversy, as it hybridizes rather easily with other varieties ${ }^{34}$, and is characterized by high seed loses before and during harvest ${ }^{35}$. A UK study led by the Centre for Ecology and Hydrology revealed that genetically modified oilseed rape crosses with a distantly related wild plant (charlock) and creates a tough herbicide-resistant strain. Such cross-fertilization had been previously discarded by the environmental experts as virtually impossible ${ }^{36}$. For the above reasons, there are concerns that GM crops may invade natural environments and that the potential spread of transgenes will be difficult to manage. Gaugitsch defined "invasiveness" as "...the result of interaction between a (hybrid) species and the ecosystem..."37, emphasizing that its parameters cannot be reasonably assessed by analyzing the traits of a plant alone with-

${ }^{27}$ Burssens \& Montagu, 1999 Why do we need genetically modified plants?. In: Highlights in European Plant Biotechnology Research and Technology Transfer. Proceedings of the Second European Conference on Plant Biotechnology, Rome, Italy, 7-9 June 1999

${ }^{28}$ Mannion, 1995 Agriculture, environment and biotechnology. Agriculture, Ecosystems \& Environment, 53 (1): 31-45

${ }^{29} \mathrm{~J}$. van den Bergh, J. Holley, op. cit.

${ }^{30}$ In: Conner, Glare \& Nap, 2003 op.cit.

${ }^{31}$ Ellstrand et al, 1999 Gene flow and introgression from domesticated plants into their wild relatives. Annual Review of Ecological Systems, 30: 539-563

${ }^{32}$ Ibidem

${ }^{33}$ Lappe \& Bailey 1998 Against the Grain: Biotechnology and the Corporate Takeover of your Food. Monroe, ME: Common Courage Press

${ }^{34}$ Gaugitsch, 2002 Experience with environmental issues in GM crop production and the likely future scenarios. Toxicology Letters, 127: 351-357

${ }^{35}$ Price et al, 1996 Seed losses on commercial harvesting of oilseed rape. Journal of Agricultural Engineering Research, 65: 183-191; Gruber et al, 2005 Life cycle and potential gene flow of volunteer oilseed rape in different tillage systems. Weed Research, 45: 83-93

${ }^{36}$ Brown, 2005 in The Guardian, 25th July GM crops created superweed. The Guardian, $25^{\text {th }}$ July

${ }^{37}$ Gaugitsch (2002), p. 354. Experience with environmental issues in GM crop production and the likely future scenarios. Toxicology Letters, 127: 351-357 
out considering the adjacent agricultural practice. Conner, Glare \& Nap ${ }^{38}$ associated "invasiveness" of transgenic plants with "weediness", suggesting that the release of GM crops may result in such plants gaining weedy characteristics and becoming agricultural weeds, difficult to fight off. Nonetheless, herbicide-resistant cultivars were also developed through conventional methods, but there was no increase of survival and spread of weeds ${ }^{39}$. It is estimated that the probability of gaining herbicide tolerance and invasiveness is no different for GM and nonGM crops ${ }^{40}$. Obviously, this potential threat should be managed, but from a perspective of agricultural strategy rather than being attributed to GM crops ${ }^{41}$. There are a number of containment strategies to help minimize or avoid gene dispersal, either already used or under development. The simplest one is to avoid growing transgenic crops near sexually-compatible wild relatives and crop rotation ${ }^{42}$. Specific timing and implementation of tillage system are also recommended ${ }^{43}$. However, even if the resistance is developed, this works only for one specific herbicide, so there is always possibility to apply another ${ }^{44}$.

\subsection{Impact on non-target species, particularly pollinators (i.e. bees)}

$\mathrm{Bt}$ is a bacterial toxin derived from soil bacteria Bacillus thuringiensis, producing proteins that are toxic to insects. Due to a high genetic diversity of these toxins and a limited spectrum of their activity, each toxin is active against a narrow number of insect families. However, this specificity works towards whole lepidopteran insect groups rather than towards single pests. Thus, there is concern that any non-target species from the same group may be affected, including beneficial insects ${ }^{45}$. Accordingly, evidence was produced that Bt pollen may harm monarch butterfly larvae and the bee population. It was reported that butterfly larvae died after a few days of eating milkweeds dusted with pollen from transgenic maize, whereas none of the larvae exposed to conventional pollen died ${ }^{46}$. Similar results were obtained by Jesse \& $\mathrm{Obrycki}^{47}$. Contrary to the former, who conducted a laboratory experiment where milkweed leaves were sprinkled with the Bt-pollen, they placed potted milkweeds in cornfields so that the Bt pollen could be deposited naturally. Nonetheless, this evidence was contradicted by large scale follow-up research, conducted by a team of 26 scientists including the aforementioned authors who initially spread the controversy ${ }^{48}$. A similar study on Bt cotton in China

\footnotetext{
${ }^{38}$ Conner, Glare \& Nap (2003) op.cit.

${ }^{39}$ (Conner \& Field, 1995) Herbicide-resistant crops: A new approach to an old problem or a radical new tool? In: McLean, G and Evand, G (Eds) Herbicide-resistant crops and pastures in Australian farming systems. Canberra: Bureau of Resource Sciences: 53-71

${ }^{40}$ (Morris, 2006) EU biotech crop regulations and environmental risk: a case of the emperor's new clothes? Trends in Biotechnology, 25 (1): 2-6

${ }^{41}$ (Dale, 1994) Potential for the environmental impact of transgenic crops. Nature Biotechnology, 20: 567-574

${ }^{42}$ (Pew Initiative on Food and Biotechnology, 2003 Have Transgenes, Will Travel: Issues Raised by Gene Flow From Genetically Engineered Crops [Internet]. The Pew Charitable Trusts. <http://www.pewtrusts.org/ our_work_detail.aspx?id=442>. [Accessed April 2008]

${ }^{43}$ (Gruber, Pekrun \& Claupein, 2004) Population dynamics of volunteer oilseed rape (Brassica napus L.) affected by tillage. European Journal of Agronomy, 20 (4): 351-361

${ }^{44}$ T. Twardowski, J. Zimny, A. Twardowska, Biobezpieczeństwo biotechnologii, 1st edition, Edytor, Poznań 2003.

${ }^{45}$ (Conner, Glare \& Nap, 2003) op.cit.

${ }^{46}$ (Losey, Rayor \& Carter, 1999) Transgenic pollen harms monarch larvae. Nature, 399: 214

${ }^{47}$ Jesse \& Obrycki (2000) Field deposition of Bt transgenic corn pollen: lethal effects on the monarch butterfly. Oecologia, 125: 241-248

${ }^{48}$ (Pew Initiative on Food and Biotechnology, 2002) Three Years Later: Genetically Engineered Corn and the Monarch Butterfly Controversy [Internet]. The Pew Charitable Trusts <http://www.pewtrusts.org/ our_work_detail.aspx?id=442>. [Accessed April 2008]
} 
also excluded eco-toxicity of this plant ${ }^{49}$. To further contradict the disastrous scenario, a Mexico observation revealed that in 2000, only 28 million monarch species hibernated in their usual habitats, while in 2001 this increased up to 100 million in the same habitat ${ }^{50}$. This optimistic change has been attributed to Bt-cotton, allowing reduction of pesticide use by 1 million liter per year in just the Southern part of the US. Another concern was that transgenic plants may decrease the health and population of bees. GM crops were blamed as one of the major reasons for the mysterious decimation of bee populations in the US and Germany ${ }^{51}$. Consequently, numerous independent experiments were carried out, in which honeybees were fed with different types of purified Bt protein, in concentrations largely exceeding their normal levels in GM crops such as maize and cotton ${ }^{52}$. Similar test was conducted on bumblebees ${ }^{53}$. None of these studies detected the slightest direct or indirect harmful effect on honeybee or bumblebee populations. Similarly, no risk to bees from herbicide tolerant oilseed rape has been identified ${ }^{54}$.

\subsection{Biodiversity of crops and wildlife}

Over recent decades, Europe has witnessed a considerable decline in the range and quantity of many species associated with agriculture. This fact questions the sustainability of conventional farming with respect to maintenance of biodiversity ${ }^{55}$. The Convention on Biological Diversity (CBD) defines biodiversity as "...the variability among living organisms from all sources [...]; this includes diversity within species, between species and ecosystems..." ${ }^{, 56}$. It is useful at this point to distinguish between agro-biodiversity and biodiversity at large (the natural environment $)^{57}$. Agro-biodiversity is a narrower term covering all components of biodiversity in agro-ecosystems that are vital to sustain its key functions, structures and processes, such as crops, livestock, wild relatives, pollinators and pests, inter alia ${ }^{58}$. In this manner, wild rela-

\footnotetext{
${ }^{49}$ (Wu, Peng \& Jia, 2003) What we have learnt on. impacts of Bt cotton on non-target organisms in China. Journal of Economic Entomology, 95: 826-831

${ }^{50}$ (Pew Initiative on Food and Biotechnology, 2002) op.cit.

${ }^{51}$ (Latsch, 2007 in De Spiegel, 22nd March. Are GM Crops Killing Bees? De Spiegel, 22 ${ }^{\text {nd }}$ March

52 (e.g. Arpaia 1996 Ecological impact of Bt-transgenic plants: 1. Assessing possible effects of cryIIIB toxin on honey bee (Apis mellifera L.) colonies. J. Genet. Breed. 50: 315-319; Malone et al, 1999 Effects of a Bacillus thuringiensis toxin, two Bacillus thuringiensis biopesticide formulations, and a soybean trypsin inhibitor on honey bee (Apis mellifera L.) survival and food consumption. Apidologie, 30 (6): 465-473; Malone \& PhamDelègue, 2001 Effects of transgene products on honey bees (Apis mellifera) and bumblebees (Bombus sp.). Apidologie, 32: 287-304, Malone, L and Pham-Delègue, M (2002) Using proteins to assess the potential impacts of genetically modified plants on honey bees. In: Devillers, J and Pham-Delègue, M (Eds.) Honey bees: estimating the environmental impact of chemicals. London, UK: Taylor \& Francis: 290-311; Malone, 2004 Potential effects of GM crops on honey bee health. Bee World, 85: 29-36; O'Callaghan et al, 2005 Effects of plants genetically modified for insect resistance on non-target organisms. Annual Review of Entomology, 50: 271-292; Sanvido 2006Ecological impacts of genetically modified crops. Experiences from ten years of experimental field research and commercial cultivation. ART-Schriftenreihe Nr. 01, Agroscope ReckenholzTänikon Research Station ART, Switzerland

${ }^{53}$ Morandin \& Winston 2003, Effects of novel pesticides on bumble bee (Hymenoptera: Apidae) colony health and foraging ability. Environmental Entomology, 32 (3): 555-563

${ }^{54}$ (Huang et al, 2004) Field and semifield evaluation of impacts of transgenic canola pollen on survival and development of worker honey bees. Journal of Economic Entomology, 97:1517-1523

55 (Hole et al, 2005) Does organic farming benefit biodiversity? Biological Conservation, 122 (1): 113-130

${ }^{56}$ (United Nations, 1993 Documents adopted by the Conference, UN sales no. E.93.I.8, United Nations, New York in: Spangenberg, 2007 Biodiversity pressure and the driving forces behind. Ecological Economics, 61: 146-158

${ }^{57}$ (Conner, Glare \& Nap, 2003) op.cit.

${ }^{58}$ (Wood \& Lenne, 1999) Agrobiodiversity: Characterization, Utiization and Management. Wallingford: CABI
} 
tives of crop plants are a source of gene spectrum for domesticated plants, and vice versa ${ }^{59}$. There is evidence for plant species richness being significantly higher on organic than conventional farms, due mainly to the elimination of synthetic pesticides and fertilizers from breeding practices, as well as maximum protection of non-cropped habitats ${ }^{60}$. This implies that organic farming is a potential cure for the reported loss of biodiversity and as such it is promoted through the EU and national subsidy payments ${ }^{61}$. With relation to transgenic crops, "biological GMO pollution" has been recognized as one of the 11 environmental "pressures" of biodiversity commonplace in almost all EU countries ${ }^{62}$. The key issue is to consider whether GM crops pose threats to biodiversity that are qualitatively and quantitatively different from conventional crops ${ }^{63}$. The main concern associated with the impact of transgenic crops on biodiversity is that biotechnology develops seeds by restricting genetic diversity to obtain uniform and predictable results. Thus, genetically modified plants may increase the homogeneity of croplands and reduce crop diversity ${ }^{64}$. This threat has been also pinpointed by FAO/WHO ${ }^{65}$. Conversely, it is highlighted that loss of biodiversity is not something specific to GM plants. Conventional agriculture is largely based on genetically narrow populations of uniform hybrids, therefore constituting a much bigger problem than transgenes ${ }^{66}$. Moreover, given the scenario of potential loss of genetic pool in the ecosystems, all varieties are present in gene banks that can replenish the system ${ }^{67}$.

\section{SUMMARY AND CONCLUSIONS}

This paper has aimed at reviewing the existing literature on the possible environmental effects of modern agricultural methods, and to compare these effects with respect to transgenic, conventional and organic agriculture. The review started from the assumption that it is not possible to elaborate on the environmental effects of these agricultural methods without referring to "sustainability" or "sustainable agricultural development". Table 1 summarizes the results of the review. Five environmental effects have been presented, namely: 1) Pollution by synthetic fertilizers and pesticides, 2) Exploitation of marginal lands and protection of natural habitats, 3) Gene flow, invasiveness and "superweeds", 4) Impact on non-target species, particularly pollinators, 5) Biodiversity of crops and wildlife, with respect to positive and negative impacts from conventional, organic and transgenic agriculture. Although these effects are usually discussed with respect to transgenic crops, we compare them with conventional and organic systems.

\footnotetext{
${ }^{59}$ J. van den Bergh, J. Holley, op. cit.

${ }^{60}$ (Hyvönen et al, 2003 Weed species diversity and community composition in organic and conventional cropping of spring cereals. Agriculture, Ecosystems \& Environment, 97(1-3): 131-149; Manhoudt, Visser \& de Snoo, 2007)_Management regimes and farming practices enhancing plant species richness on ditch banks. Agriculture, Ecosystems \& Environment, 119(3-4): 353-358

${ }^{61}$ Hole et al, 2005) op.cit.

${ }^{62}$ (Spangenberg, 2007) Biodiversity pressure and the driving forces behind. Ecological Economics, 61: 146-158

${ }^{63}$ (Conner, Glare \& Nap, 2003) op.cit.

${ }^{64}$ (Witcombe, 1999) Do farmer-participatory methods apply more to high potential areas than to marginal ones? Outlook on Agriculture, 28

${ }^{65}$ FAO/WHO (2001) Codex Alimentarius: HACCP System and Guidelines for its Application. Food Hygiene Basic Texts, FAO/WHO, Rome 2001

${ }^{66}$ (Louwaars et al, 2002) The Biosafety Files, a new link in biosafety information. Biotechnology and Development Monitor, 49: 13-14

${ }^{67}$ (Conner, Glare \& Nap, 2003)op.cit.
} 
Table 1. Summary on environmental factors from conventional, organic and transgenic agriculture

\begin{tabular}{|c|c|c|c|}
\hline & \multicolumn{3}{|c|}{ Farming systems and examples of the environmental effects } \\
\hline $\begin{array}{l}\text { ENVIRONMENTAL } \\
\text { EFFECTS }\end{array}$ & CONVENTIONAL & ORGANIC & TRANSGENIC \\
\hline $\begin{array}{l}\text { Pollution by synthetic } \\
\text { fertilizers and pesti- } \\
\text { cides }\end{array}$ & $\begin{array}{l}\text { Negative: Increasing } \\
\text { pollution by synthetic } \\
\text { fertilizers and pesti- } \\
\text { cides }\end{array}$ & $\begin{array}{l}\text { Positive: Reduced } \\
\text { pollution by synthet- } \\
\text { ic fertilizers and } \\
\text { pesticides }\end{array}$ & $\begin{array}{l}\text { Positive: Reduced } \\
\text { pollution by synthet- } \\
\text { ic fertilizers and } \\
\text { pesticides }\end{array}$ \\
\hline $\begin{array}{l}\text { Conservation of soils } \\
\text { and natural habitats }\end{array}$ & $\begin{array}{l}\text { Negative: Pollution of } \\
\text { soils by synthetic } \\
\text { fertilizers and pesti- } \\
\text { cides with increasing } \\
\text { invasion to natural } \\
\text { ecosystems }\end{array}$ & $\begin{array}{l}\text { Positive: Sympathet- } \\
\text { ic soil management, } \\
\text { protection of natural } \\
\text { ecosystems }\end{array}$ & $\begin{array}{l}\text { Positive: Possibility } \\
\text { to use marginal } \\
\text { lands for farming } \\
\text { purposes, allowing } \\
\text { avoidance of con- } \\
\text { verting natural } \\
\text { habitats into farm- } \\
\text { lands }\end{array}$ \\
\hline $\begin{array}{l}\text { Gene flow, invasive- } \\
\text { ness and super weeds }\end{array}$ & $\begin{array}{l}\text { Negative: Transfer of } \\
\text { herbicide tolerance to } \\
\text { wild relatives of } \\
\text { cultivated plants or } \\
\text { invasiveness, and } \\
\text { creation of weeds } \\
\text { resistant to herbicides }\end{array}$ & $\begin{array}{l}\text { Positive: No risk of } \\
\text { creation of } \\
\text { superweeds }\end{array}$ & $\begin{array}{l}\text { Negative: Creation of } \\
\text { weeds resistant to } \\
\text { herbicides }\end{array}$ \\
\hline $\begin{array}{l}\text { Impact on non-target } \\
\text { species, especially } \\
\text { pollinators }\end{array}$ & $\begin{array}{l}\text { Negative: Extensive } \\
\text { use of pesticides may } \\
\text { be harmful to pollina- } \\
\text { tors }\end{array}$ & $\begin{array}{l}\text { Positive: Reduced } \\
\text { use of pesticides } \\
\text { protects pollinator } \\
\text { populations }\end{array}$ & $\begin{array}{l}\text { Positive: Reduced } \\
\text { use of pesticides } \\
\text { protects pollinator } \\
\text { populations } \\
\text { Negative: Inherent } \\
\text { bacterial toxin } \mathrm{Bt} \\
\text { harmful to monarch } \\
\text { butterfly and bees }\end{array}$ \\
\hline $\begin{array}{l}\text { Biodiversity of crops } \\
\text { and wildlife }\end{array}$ & $\begin{array}{l}\text { Negative: Reduced } \\
\text { genetic diversity of } \\
\text { seeds - promotes } \\
\text { monocultures }\end{array}$ & $\begin{array}{l}\text { Positive: Protection } \\
\text { of biodiversity due } \\
\text { to elimination of } \\
\text { pesticides and pro- } \\
\text { tection of natural } \\
\text { habitats }\end{array}$ & $\begin{array}{l}\text { Negative: Reduced } \\
\text { genetic diversity of } \\
\text { seeds - promotes } \\
\text { monocultures }\end{array}$ \\
\hline
\end{tabular}

The review shows that conventional farming is definitely "negative" to the environment, while organic agriculture presents only positive effects. Each factor, except for the "Gene flow, invasiveness and superweeds", may have a positive and negative side dependent on the farming system. For example, conventional crops require the use of a large amount of synthetic fertilizers and pesticides, while organic and GM systems reduce the need for it. It is also worthy to note that some risks typically associated with transgenic crops, i.e. decline in genetic biodiversity, may be also inherent in conventional agriculture. From the environmental point of view, the organic system seems the most "sustainable", as it is free of negative effects of transgenic and conventional farming systems. On the other hand, it may not satisfy the growing demand for food. In order to state whether one or another agricultural system is "sustainable", we need to consider its health and economic impact, which have been subjects of other studies. 
However, it would be too simple to assume that GMO is placed somewhere between the organic and conventional production in terms of sustainability and environmental effects. In addition, since there is uncertainty about the future effects of GMO, a systematic risk analysis is needed, addressing all potential and existing effects not only to the environment, but also to human health. Moreover, it also requires consideration of the consumer concerns about biotechnology ${ }^{68}$.

\section{REFERENCES}

[1] 97/618/EC, Commission Recommendation of 29 July 1997 concerning the scientific aspects and the presentation of information necessary to support applications for the placing on the market of novel foods and novel food ingredients and the preparation of initial assessment reports under Regulation (EC) No 258/97 of the European Parliament and of the Council (Text with EEA relevance)

[2] Al-Babili S., Beyer P., Golden Rice - five years on the road - five years to go?, "Trends in Plant Science" 10/12 (2005), p. 565-573.

[3] Anderson D., Biotechnology Risks Management: The Case of Genetically Modified Organisms (GMOs), "CPCU Journal" 2001.

[4] Bertolla F., Simonet P., Horizontal gene transfers in the environment: natural transformation as a putative process for gene transfers between transgenic plants and microorganisms, "Res. Microbiol." 150/6 (1999), p. 375-384.

[5] Celec P., Kukuckova M., Renczesova et al., Biological and biomedical aspects of genetically modified food, "Biomed Pharmacother" 2005/59, p. 531-540.

[6] Commission Regulation (EC), No 641/2004 of 6 April 2004 on detailed rules for the implementation of Regulation (EC) No 1829/2003 of the European Parliament and of the Council as regards the application for the authorisation of new genetically modified food and feed, the notification of existing products and adventitious or technically unavoidable presence of genetically modified material which has benefited from a favourable risk evaluation.

[7] Core J. New Rice Line Could Benefit Malnourished Populations. USDA Agricultural Research Service 2002, http://www.ars.usda.gov/is/pr/2002/020913.htm (accessed: January 2008).

[8] Davidson E., A view from the genome: spatial control of transcription in sea urchin development, "Curr. Opinion Genetics Development" 9/5 (1999), p. 530-541.

[9] Directive 2001/18/EC of the European Parliament and of the Council of 12 March 2001 on the deliberate release into the environment of genetically modified organisms (repealing Council Directive 90/220/EEC).

[10] Executive Summary, Genetically modified foods for human health and nutrition: the scientific basis for benefit/risk assessment, "Trends Food Sci. Technol." 2003/14, p. 173-181.

[11] FAO/WHO, Codex Alimentarius: HACCP System and Guidelines for its Application. Food Hygiene Basic Texts, FAO/WHO, Rome 2001.

[12] Finucane M., Holup J., Psychosocial and cultural factors affecting the perceived risk of genetically modified food: an overview of the literature, "Social Sci. Medicine" 2005/60, p. 1603-1612.

[13] Food Biotechnology, A Communications Guide to Improving Understanding, 2012, http://www.foodinsight.org/Resources/Detail.aspx?topic=Food_Biotechnology_A_Communication s_Guide_to_Improving_Understanding_(accessed December 2013).

[14] Frenich A., Bolaños P., Vidal J., Multiresidue analysis of pesticides in animal liver by gas chromatography using triple quadrupole tandem mass spectrometry, "J. Chromatography A" 1153/1-2 (2007), p. 194-202.

\footnotetext{
${ }^{68}$ G. Rowe, How can genetically modified foods be made publicly acceptable?, "Trends in Biotechnology" 22/3 (2004), p. 107-109.
} 
[15] Gebhard F., Smalla K. Monitoring field releases of genetically modified sugar beets for persistence of transgenic plant DNA and horizontal gene transfer, "FEMS Microbiol Ecol." 28/3 (1999), p. 261-272.

[16] Gertsberg D., Loss of Biodiversity and Genetically Modified Crops, "GMO Journal, Food Safety Politics" 2011, http://gmo-journal.com/2011/06/17/loss-of-biodiversity-and-genetically-modifiedcrops/ (accessed December 2013).

[17] Guttieria M., Bowena D., Dorschb J. et al., Identification and characterization of a low phytic acid wheat, "Crop Sci" 2004/44, p. 418-424.

[18] Leff L., Dana J., McArthur J. et al., Detection of Tn5-like sequences in kanamycin-resistant stream bacteria and environmental DNA, "Applied and Environmental Microbiology" 1993/59, p. 417-421.

[19] Lesueur C., Knittl P., Gartner M. et al., Analysis of 140 pesticides from conventional farming foodstuff samples after extraction with the modified QuECheRS method, "Food Control" 19/9 (2008), p. 906-914.

[20] Lopez-Espinosa M., Lopez-Navarrete E., Rivas A. et al., Organochlorine pesticide exposure in children living in southern Spain, "Environm Res" 106/1 (2008), p. 1-6.

[21] Mota M., Empis J., Novel foods and food ingredients: what is the mission of scientists and technologists?, "Trends Food Sci. Technol." 11/4-5 (2000), p. 161-168.

[22] Nielsen K., Bones A., Smalla K. et al., Horizontal gene transfer from transgenic plants to terrestrial bacteria - a rare event?, "FEMS Microbiol Rev." 22/2 (1998), p. 79-103.

[23] Noussair S., Do consumers really refuse to buy genetically modified food?, "Econom. J." 114/1 (2004), p. 102-120.

[24] Novak W., Haslberger A. Substantial equivalence of antinutrients and inherent plant toxins in genetically modified novel foods, "Food Chem. Toxicol." 38/6 (2000), p. 473-483.

[25] Pelizzoni L., Democracy and the governance of uncertainty. The case of agricultural gene technologies, "J. Hazard. Materials" 2001/86, p. 205-222.

[26] Porta M., Puigdomènech E., Ballester F. et al., Monitoring concentrations of persistent organic pollutants in the general population: The international experience, "Environm. Internat." 34/4 (2008), p. 546-561.

[27] Potrykus I., Nutritionally enhanced rice to combat malnutrition disorders of the poor, "Nutr. Rev." 61/6 (2003), p. S101-S104.

[28] Prusak A., Schlegel-Zawadzka M., Food health quality of genetically modified crops - review of risks and benefits, "Military Pharmacy and Medicine" 2013/VI-2, p. 13-18.

[29] Purchase I: What determines the acceptability of genetically modified food that can improve human nutrition?, "Toxicol. Appl. Pharmacol." 2005/207: S19-S27.

[30] Rowe G., How can genetically modified foods be made publicly acceptable?, "Trends in Biotechnology" 22/3 (2004), p. 107-109.

[31] Schmidt Ch.W., Genetically Modified Foods: Breeding Uncertainty, "Environm Health Perspect." 113/8 (2005), p. 526-533.

[32] Smalla K., van Overbeek L., Pukall R. et al., Prevalence of NPTII and Tn5 in Kanamycin Resistant Bacteria From Different Environments, "FEMS Microbiol. Ecol."1993/13, p. 47-58.

[33] Statement of the Scientific Panel on Genetically Modified Organisms on the safe use of the nptII antibiotic resistance marker gene in genetically modified plants, EFSA 2007, http://www.efsa.europa.eu/EFSA/efsa_locale-1178620753812_1178620775641.htm (accessed February 2007).

[34] Twardowski T., Zimny J., Twardowska A., Biobezpieczeństwo biotechnologii, 1st edition, Edytor, Poznań 2003.

[35] van den Bergh J., Holley J., An environmental-economic assessment of genetic modification of agricultural crops, "Futures" 34/9-10 (2002), p. 807-822.

[36] Wagner W., Sustainable agriculture: how to sustain a production system in a changing environment, "International Journal for Parasitology" 29/1 (1999), p. 1-5.

[37] Weggleński P., GMO, “Aura” 2006/2. 
[38] Ikerd, J (1993) The need for a system approach to sustainable agriculture. Agriculture, Ecosystems \& Environment, 46 (1-4): 147-160;

[39] Ikerd, J quoted by Duesterhaus, 1990 in: Sustainability's Promise, Journal of Soil and Water Conservation (Jan.-Feb. 1990) 45 (1): p.4.

[40] Earles, R. (2005) Sustainable agriculture: An Introduction. [Internet]. ATTRA. $<$ http://attra.ncat.org/attra-pub/summaries/sustagintro.html>. [Accessed $11^{\text {th }}$ April 2008]

[41] Champeil, A, Fourbet, J, Doré, T and Rossignol, L (2004) Influence of cropping system on Fusarium head blight and mycotoxin levels in winter wheat. Crop Protection, 23 (6): 531-537

[42] Eicher, A (2003) Organic Agriculture. A Glossary of Terms for Farmers and Gardeners. [Internet]. University of California Cooperative Extension. <http://www.cehumboldt. ucdavis.edu/files/8286.pdf $>$. [Accessed $11^{\text {th }}$ April 2008]

[43] Pacini, C, Wossink, A, Giesen, G, Vazzana, C and Huirne, R (2003) Evaluation of sustainability of organic, integrated and conventional farming systems: a farm and field-scale analysis. Agriculture, Ecosystems \& Environment, 95 (1): 273-288

[44] Andow, D and Hidaka K (1998) Yield loss in conventional and natural rice farming systems. Agriculture, Ecosystems \& Environment, 70 (2-3): 151-158

[45] Clark, M, Horwath, W, Shennan, C, Scow, K, Lantni, T and Ferris, H (1999) Nitrogen, weeds and water as yield-limiting factors in conventional, low-input, and organic tomato systems. Agriculture, Ecosystems \& Environment, 73 (3): 257-270

[46] Levidow, L and Boschert, K (2008) Coexistence or contradiction? GM crops versus alternative agricultures in Europe. Geoforum, 39 (1): 174-190

[47] Linacre, N, Gaskell, J, Rosegrant, M, Falck-Zapeda, J, Quemada, H, Halsey, M and Birner, R (2006) Strategic environmental assessment for genetically modified organisms. Impact Assessment and Project Appraisal, 24 (1): 35-43

[48] Renn, O (1992) Risk communication: towards a rational discourse with the public. Journal of Hazardous Materials, 29: 465-519

[49] Slovic P (2001) The risk game. Journal of Hazardous Materials, 86 (1-3): 17-24

[50] FAO/WHO (1995) Application of risk analysis to food standards issues. Report on the joint FAO/WHO expert consultation, Geneva, Switzerland, 13-17 March 1995

[51] Prudente, M, Malarvannan, G and Tanabe, S (2007) Persistent Toxic Substances in the Philippine Environment. Developments in Environmental Sciences, 7: 559-585

[52] Gui, W-J, Wang, S-T, Guo, Y-R and Zhu, G-N (2008) Development of a one-step strip for the detection of triazophos residues in environmental samples. Analytical Biochemistry, In Press, Uncorrected Proof, Available online 14 March 2008

[53] Phipps, R and Park, J (2002) Environmental benefits of genetically modified crops: global and European perspectives on their ability to reduce pesticide use. Journal of Animal and Feed Sciences, 11: 1-18

[54] Tilman, D, Reich, P, Knops, J, Wedin, D, Mielke, T and Lehman, C (2001) Diversity and Productivity in a Long-Term Grassland Experiment. Science, 294 (5543): 843-845

[55] Burssens, S and van Montagu, M (1999) Why do we need genetically modified plants?. In: Highlights in European Plant Biotechnology Research and Technology Transfer. Proceedings of the Second European Conference on Plant Biotechnology, Rome, Italy, 7-9 June 1999

[56] Mannion, A (1995) Agriculture, environment and biotechnology. Agriculture, Ecosystems \& Environment, 53 (1): 31-45

[57] Conner, A, Glare, T and Nap, J-P (2003) The release of genetically modified cops into the environment. Part II: Overview of ecological assessment. The Plant Journal, 33: 19-46

[58] Ellstrand, N, Prentice, H and Hancock, J (1999) Gene flow and introgression from domesticated plants into their wild relatives. Annual Review of Ecological Systems, 30: 539-563

[59] Lappe, M and Bailey, B (1998) Against the Grain: Biotechnology and the Corporate Takeover of your Food. Monroe, ME: Common Courage Press

[60] Gaugitsch, H (2002) Experience with environmental issues in GM crop production and the likely future scenarios. Toxicology Letters, 127: 351-357 
[61] Price, J, Hobson, R, Neale, M and Bruce, D (1996) Seed losses on commercial harvesting of oilseed rape. Journal of Agricultural Engineering Research, 65: 183-191

[62] Brown, P (2005) GM crops created superweed. The Guardian, $25^{\text {th }}$ July

[63] Gruber, S, Pekrun, C and Claupein, W (2005) Life cycle and potential gene flow of volunteer oilseed rape in different tillage systems. Weed Research, 45: 83-93

[64] Conner, A and Field, R (1995) Herbicide-resistant crops: A new approach to an old problem or a radical new tool? In: McLean, G and Evand, G (Eds) Herbicide-resistant crops and pastures in Australian farming systems. Canberra: Bureau of Resource Sciences: 53-71

[65] Morris, S (2006) EU biotech crop regulations and environmental risk: a case of the emperor's new clothes? Trends in Biotechnology, 25 (1): 2-6

[66] Dale, P, Clarke, B and Fontes, E (2002) Potential for the environmental impact of transgenic crops. Nature Biotechnology, 20: 567-574

[67] Pew Initiative on Food and Biotechnology (2003) Have Transgenes, Will Travel: Issues Raised by Gene Flow From Genetically Engineered Crops [Internet]. The Pew Charitable Trusts. <http://www.pewtrusts.org/our_work_detail.aspx?id=442>. [Accessed April 2008]

[68] Gruber, S, Pekrun, C and Claupein, W (2004) Population dynamics of volunteer oilseed rape (Brassica napus L.) affected by tillage. European Journal of Agronomy, 20 (4): 351-361

[69] Conner, A, Glare, T and Nap, J-P (2003) The release of genetically modified cops into the environment. Part II: Overview of ecological assessment. The Plant Journal, 33: 19-46

[70] Losey, J, Rayor, L and Carter, M (1999) Transgenic pollen harms monarch larvae. Nature, 399: 214

[71] Jesse, L and Obrycki, J (2000) Field deposition of Bt transgenic corn pollen: lethal effects on the monarch butterfly. Oecologia, 125: 241-248

[72] Pew Initiative on Food and Biotechnology (2003) Have Transgenes, Will Travel: Issues Raised by Gene Flow From Genetically Engineered Crops [Internet]. The Pew Charitable Trusts. <http://www.pewtrusts.org/our_work_detail.aspx?id=442>. [Accessed April 2008]

[73] Wu, K, Peng,Y and Jia, S (2003) What we have learnt on. impacts of Bt cotton on non-target organisms in China. Journal of Economic Entomology, 95: 826-831

[74] Pew Initiative on Food and Biotechnology (2002) Three Years Later: Genetically Engineered Corn and the Monarch Butterfly Controversy [Internet]. The Pew Charitable Trusts <http://www.pewtrusts.org/our_work_detail.aspx?id=442>. [Accessed April 2008]

[75] Latsch, G (2007) Are GM Crops Killing Bees? De Spiegel, $22^{\text {nd }}$ March

[76] Arpaia, S. 1996. Ecological impact of Bt-transgenic plants: 1. Assessing possible effects of cryIIIB toxin on honey bee (Apis mellifera L.) colonies. J. Genet. Breed. 50: 315-319.

[77] Malone, L (2004) Potential effects of GM crops on honey bee health. Bee World, 85: 29-36

[78] Malone, L and Pham-Delègue, M (2001) Effects of transgene products on honey bees (Apis mellifera) and bumblebees (Bombus sp.). Apidologie, 32: 287-304.

[79] Malone, L and Pham-Delègue, M (2002) Using proteins to assess the potential impacts of genetically modified plants on honey bees. In: Devillers, J and Pham-Delègue, M (Eds.) Honey bees: estimating the environmental impact of chemicals. London, UK: Taylor \& Francis: 290-311

[80] O'Callaghan, M, Glare, T, Burgess, E and Malone, L (2005) Effects of plants genetically modified for insect resistance on non-target organisms. Annual Review of Entomology, 50: 271-292

[81] Sanvido, O, Stark, M, Romeis, J and Bigler, F (2006) Ecological impacts of genetically modified crops. Experiences from ten years of experimental field research and commercial cultivation. ART-Schriftenreihe Nr. 01, Agroscope Reckenholz-Tänikon Research Station ART, Switzerland

[82] Morandin, L and Winston, M (2003) Effects of novel pesticides on bumble bee (Hymenoptera: Apidae) colony health and foraging ability. Environmental Entomology, 32 (3): 555-563

[83] Huang, Z, Hanley, A, Pett, W, Langenberger, M and Duan, J (2004) Field and semifield evaluation of impacts of transgenic canola pollen on survival and development of worker honey bees. Journal of Economic Entomology, 97:1517-1523 
[84] Hole, D, Perkins, A, Wilson, J, Alexander, I, Grice, P and Evans, A (2005) Does organic farming benefit biodiversity? Biological Conservation, 122 (1): 113-130

[85] United Nations (1993) Documents adopted by the Conference, UN sales no. E.93.I.8, United Nations, New York

[86] Wood, D and Lenne, J (Eds) (1999) Agrobiodiversity: Characterization, Utiization and Management. Wallingford: CABI

[87] Hyvönen, T, Ketoja, E, Salonen, J, Jalli, H and Tiainen, J (2003) Weed species diversity and community composition in organic and conventional cropping of spring cereals. Agriculture, Ecosystems \& Environment, 97(1-3): 131-149

[88] Manhoudt, A, Visser, A and de Snoo, G (2007) Management regimes and farming practices enhancing plant species richness on ditch banks. Agriculture, Ecosystems \& Environment, 119(3-4): 353-358

[89] Spangenberg, J (2007) Biodiversity pressure and the driving forces behind. Ecological Economics, 61: 146-158

[90] Witcombe, J (1999) Do farmer-participatory methods apply more to high potential areas than to marginal ones? Outlook on Agriculture, 28

[91] FAO/WHO (2001) Codex Alimentarius: HACCP System and Guidelines for its Application. Food Hygiene Basic Texts, FAO/WHO, Rome 2001

[92] Louwaars, N, Brandenburg, W, Gilissen, L, Kleter, G and Wagenaar, J (2002) The Biosafety Files, a new link in biosafety information. Biotechnology and Development Monitor, 49: 13-14

\section{CZY GMO JEST ,ZRÓWNOWAŻONE”? PRZEGLĄD EFEKTÓW ODDZIALY- WANIA NA ŚRODOWISKO ROŚLIN GMO W PORÓWNANIU Z EFEKTAMI UPRAW KONWENCJONALNYCH ORAZ EKOLOGICZNYCH}

Prezentowany artykuł ma na celu dokonanie przeglądu potencjalnego i istniejącego ryzyka dla środowiska naturalnego, związanego ze stosowaniem upraw genetycznie zmodyfikowanych (GMO). Przeglądem objęto ponad 30 artykułów zamieszczonych w bazie Science Direct dotyczących wpływu upraw transgenicznych na środowisko. Na tej podstawie zidentyfikowano pięć głównych efektów wpływu rolnictwa na środowisko: 1) zanieczyszczenie spowodowane stosowaniem nawozów sztucznych i środków ochrony roślin, 2) możliwość eksploatacji gruntów marginalnych i ochrona naturalnych siedlisk przyrodniczych, 3) transfer genów, inwazyjność oraz powstanie tzw. ,,superchwastów”, 4) wpływ na inne gatunki, w tym zapylacze, szczególnie istotne dla ekosystemów, 5) bioróżnorodność roślin i zwierząt. Mimo że efekty te kojarzone są zazwyczaj z rolnictwem GMO, autorzy artykułu rozszerzyli tę dyskusję również na rolnictwo konwencjonalne oraz ekologiczne. Analiza porównawcza tych trzech rodzajów upraw wykazała, że oprócz czynnika 3) transfer genów i powstanie „superchwastów” (który to efekt jest specyficzny dla GMO), każdy z wymienionych czynników może mieć zarówno pozytywny, jak i negatywny wpływ na środowisko naturalne. Na przykład rolnictwo konwencjonalne wymaga stosowania dużej ilości środków ochrony roślin, w przeciwieństwie do upraw ekologicznych, podczas gdy uprawy transgeniczne zmniejszają potrzebę użycia pestycydów przy zachowaniu odpowiedniego plonu. Co więcej, niektóre ryzyko utożsamiane z GMO może wynikać także z upraw konwencjonalnych (np. zmniejszenie bioróżnorodności, które szacowane jest na podobnym poziomie jak w wypadku upraw GMO).

Słowa kluczowe: GMO, zrównoważony rozwój, produkcja żywności, zagrożenia środowiskowe

\section{DOI: $10.7862 / \mathrm{rz} .2014 . \mathrm{mmr} .55$}

Tekst złożono w redakcji: grudzień 2014

Przyjęto do druku: styczeń 2015 